\title{
Conjunctivitis in a Juvenile Red-Eared Slider (Trachemys scripta elegans)
}

\section{Konjungtivitis pada Anakan Kura-Kura Brazil (Trachemys scripta elegans)}

Puveanthan Nagappan Govendan ${ }^{1 *}$, Steven Dwi Purbantoro ${ }^{2}$, Gabriella Jenni Alfades Loa ${ }^{2}$, Erika $^{2}$, Zefanya Christiani ${ }^{2}$, Carene Naomi ${ }^{2}$, Sulham Sunusi ${ }^{2}$, I Made Beratha Mukti ${ }^{2}$

${ }^{1}$ Student of Veterinary Medicine Faculty, Gadjah Mada University, Yogyakarta

${ }^{2}$ Student of Veterinary Medicine Faculty, Udayana University, Bali

*E-mail: puvean89@gmail.com

\begin{abstract}
Conjunctivitis is a common problem among red-eared sliders (Trachemys scripta elegans) with improper husbandry care. A 30 grams T. s. elegans was presented with complaints of anorexia, dullness, inflamed, and closed eyes. The owner informed that the turtle was kept indoors without ultraviolet B (UVB) light or sunlight exposure and the water was not changed by the owner for a week. Clinical examination showed inflammation and watery discharge was found on the left eye. Conjunctivitis was diagnosed based on history and clinical examination. Treatments consist of topical antibiotic drops, vitamin A and B-complex, and husbandry care improvement. The turtle started eating five days after treatment. Ten days after the treatment the turtle was brought back for a checkup and eye have recovered.
\end{abstract}

Keywords: Trachemys scripta elegans, conjunctivitis

\begin{abstract}
ABSTRAK
Konjungtivitis merupakan salah satu gangguan kesehatan yang umum ditemukan pada kura-kura Brazil (Trachemys scripta elegans) di penangkaran dengan pemeliharaan yang kurang baik. Seekor anakan $T$. s. elegans dengan bobot badan 30 gram dilaporkan mengalami anoreksia, kurang responsif, mengalami peradangan pada mata sehingga mata tertutup. Pemilik menyatakan bahwa air tidak diganti selama seminggu dan kura-kura dipelihara di dalam ruangan tanpa cahaya UVB atau sinar matahari. Pemeriksaan klinis menunjukkan peradangan dan leleran bening pada mata kiri. Diagnosis konjungtivitis disimpulkan berdasarkan riwayat dan pemeriksaan klinis. Pengobatan terdiri dari antibiotik tetes mata, vitamin A dan B-kompleks dan perawatan pada penangkaran diperbaiki. Kurakura mulai makan pada hari kelima setelah pengobatan. Sepuluh hari setelah pengobatan, kura-kura diperiksa dan dinyatakan konjungtiva telah sembuh.
\end{abstract}

Kata kunci: Trachemys scripta elegans, conjunctivitis

\section{INTRODUCTION}

Red-eared sliders (Trachemys scripta elegans) are the most common turtle species in the pet trade. This particular species can grow up to $24 \mathrm{~cm}$ (carapace length) (Close and Seigel, 1997). It is common for owners to release the turtles to the pond or river nearby once they are unable to provide a bigger enclosure (Chaudhuri et al., 2018; Zhang et al., 2019). This particular species has been labeled as an invasive species in many parts of the world. This turtle species has a very high tolerance level of adaptation. It has been found 
reproducing in many non-native areas with different ecology (Zhang et al., 2019).

Red-eared sliders are prone to various diseases relating to their husbandry management. Younger turtles are prone to acute metabolic issues. Vitamin A deficiency is related to conjunctivitis in turtles (Tanase et al., 2014). Chelonians in general have functional eyelids with palpebral fissures (Lawton, 2006). Common clinical signs of hypovitaminosis A in turtles are edema of eyelids, exophthalmia and, conjunctivitis (Tanase et al., 2014).

Eye infection is one of the most common problems in slider species, especially with hatchlings and juveniles. Lack of education by turtle vendors regarding proper husbandry care is one of the main reasons for this problem. Regular water changes are important to reduce the possibilities of pathogens in the water. Ultra-violet B (UVB) is an important component to stimulate vitamin $\mathrm{D}_{3}$ synthesis in ectothermic animals, such as reptiles (Alarcon, 2016). In non-seasonal countries, sunlight is available all year round. Outdoor enclosures will help the thermoregulation of the species by basking frequently. However, UVB lighting could be facilitated by owners when turtles are kept indoors (Oonincx and Leeuwen, 2017).

\section{CASE HISTROY}

\section{Signalment}

An unsexed young juvenile 30 grams red-eared slider (Trachemys scripta elegans).

\section{Anamnesis}

Anorexic for 3 days, inflamed conjunctiva, kept in a $15 \times 10 \mathrm{~cm}$ container indoors with no sunlight for 2 weeks. The water was $5 \mathrm{cms}$ in-depth and was rarely changed. Feeding was performed in the same container.

\section{Clinical Examination}

No nasal discharge was noticed. Bilateral watery eye, left eye was inflamed, and hyperemia on the conjunctiva. Pupil, menace, and palpebral reflex exam were all positive.

\section{Diagnosis}

Conjunctivitis due to hypovitaminosis A. Prognosis was dubious for this patient.

\section{Treatment}

Husbandry correction - outdoor enclosure, force-feeding (Royal Canin Recovery®) - [2 grams of food were diluted with $0.2 \mathrm{~mL}$ of drinking water] and vitamin A (IPI tablet) with a wing needle with the needle removed, one drop of B-complex were administered PO once daily on the beak of the turtle, and one drop of chloramphenicol eye one drop was administered on the left eye twice daily. The turtle was placed for almost 30 minutes on dry-dock after the chloramphenicol eye drops were administered.

\section{Evaluation}

After 5 days of treatment, the inflammation on the conjunctiva subsided. The turtle started eating. On the 10th days of treatment, the turtle's left eye was normal with clear and uninflamed conjunctiva.

\section{DISCUSSION}

Red-eared sliders among the most common turtle species have good 
reproductive rate capacity (Zhang et al., 2019). This allows reptile vendors to sell them for a small price. Being extremely cheap in the market will allow people with no background of reptile-keeping venture into the new passion by getting a slider as a pet. This is one of the main reasons this chelonian species is found very commonly presented with the most health issues in veterinary practices.

Conjunctivitis could be identified in the species presented with inflamed eyes (Sharun et al., 2019). Conjunctivitis is a common sign of hypovitaminosis A in captive turtles (Tanase et al., 2014). Vitamin A is known as having the roles in epithelial cell formation, maturation, and metabolism (Tanase et al., 2014). The deficiency in vitamin A may lead to a continual breakdown of the eye epithelial tissue (Lawton, 2006). Further, the keratinized squamous epithelium will replace mucus-secreting cells and accumulate at the ducts which may lead to dilation of gland lamina that will cause swollen eyelids and blocking of the ducts that inhibit tear productions. The eye will lose its protection, nutrition, and lubrication and lead opportunistic bacteria to infect the host which causes conjunctivitis (Fleming, 2019).

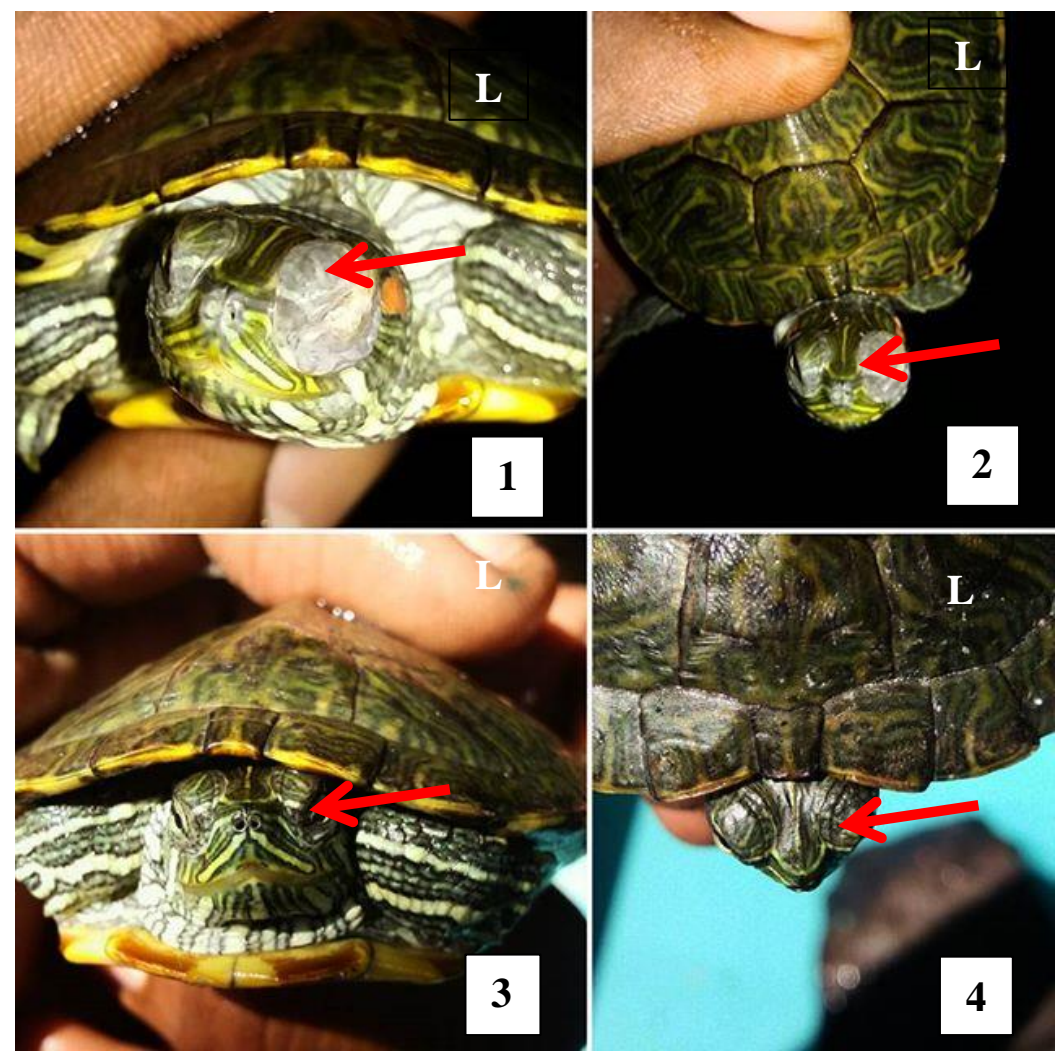

Figure 1. Pre-treatment of the red-eared slider with conjunctivitis. An inflamed eye can be seen by (1) anterior view and (2) in dorsal view. ( $3 \& 4)$. The slider presented healthy on day 10 with both left and right eye looking symmetrical with no discharge or inflammation.

Eye infection in chelonians could be caused by improper husbandry, malnourished, congenital, and traumatic lesion (Fleming, 2019). Commonly identified pathogens of eye infections are Aeromonas hydrophyla, Bacillus sp.,
Proteus vulgaris, Pseudomonas sp., and Staphylococcus aureus (Somma et al., 2014; Isler et al., 2015).

Husbandry correction for the turtle was recommended to the client. Sharun et al. (2019) mentioned that nutrition and 
the environment is an important role in controlling stress to prevent these issues. Essential nutrients such as proteins, vitamins, and minerals should be provided for development and physiological purposes (Tanase et al., 2014). Royal Canin Recovery was chosen for the turtle which is rich in nutrients as mentioned before. Isler et al. (2015) reported dirty water in turtle housing caused bilateral conjunctivitis.

Topical chloramphenicol eye drops were administered twice daily for 7 days. The antibiotic in the study was used in regard to eliminating bacteria that cause conjunctivitis in the turtle, which was the

\section{REFERENCES}

Alarcon, E., 2016, Effects of ultraviolet B on the behavior of red-eared sliders (Trachemys scripta elegans). $\mathrm{PhD}$ dissertation, City University of New York. New York.

Chaudhuri, A., Banerjee, A., Chowdhury, S., Deuti, K., 2018, "Report of red-eared slider (Trachemys scripta elegans) from a wetland near Kolkata, West Bengal, India", The Herpetological Bulletin 146, pp. 41-42.

Close, L.M., Seigel, R.A., 1997, "Differences in Body Size Among Populations of Red-Eared Sliders (Trachemys scripta elegans) Subjected to Different Levels of Harvesting", Chelonian Conservation and Biology, 2(4), pp. 563-566.

Fleming, K.M.S., 2019, "Ocular surface disease in reptiles", Vet Clin Exot Anim, 22, pp. 109-121, https://doi.org/10.1016/j.cvex.2018.08. $\underline{006}$

Isler, C.T., Altug, M.E., Secer, F.S., Cantekin, Z., 2015, "Treatment of bath with enrofloxacin in red-eared sliders (Trachemys scripta elegans) suffer secondary cause of the condition. The turtle was placed in a dry environment to give better drug penetration from the topical antibiotic. Vitamin A was crushed and diluted for PO administration using a wing needle tube (with the needle removed) at the dose of $5000 \mathrm{IU} / \mathrm{kg}$ once every other day for 5 times. During this same time, the turtle was force-fed with a diluted canned dog and cat food (Royal Canin Recovery). Vitamin B-complex was administered $\mathrm{PO}$ at $0.02 \mathrm{~mL}$ daily for three days. Supplementation of vitamin A, Bcomplex, and canned dog food was given.

from conjunctivitis and its results", Kafkas Univ Vet Fak Derg, 21(3), pp. 429-431.

http://doi.org/10.9775/kvfd.2014.1262 1

Lawton, M.P.C., 2006, Reptilian Ophthalmology in Mader DR $2^{\text {nd }}$ ed. Reptile Medicine and Surgery. St Louis: Saunders Elsevier. pp. 323-342.

Oonincx, D., Leeuwen, J.V., 2017, "Evidence-based reptile housing and nutrition", Vet Clin Exot Anim, 20, pp. 885-898.

Pee, S.D., West, C.E., Muhilal, Karyadi, D., Hautvast, J.G.A.J., 1995, "Lack of improvement in vitamin A status with increased consumption of dark-green leafy vegetables", Lancet, 346, pp. 7581.

Sharun, K., Panikkassery, S., Sidhique, S.A., 2019, "Medical management of conjunctivitis and shell rot in a redeared slider (Trachemys scripta elegans)", Comparative Clinical Pathology, 28, pp. 575-577. https://doi.org/10.1007/s00580-01902911-4. 
Somma, A.T., Lima, L., Lange, R.R., Giannico, A.T., Ferreira, F.M., 2014, "The eye of the red-eared slider turtle: morphologic observations and reference values for selected ophthalmic diagnostic tests", Veterinary Ophthalmology, pp. 1-10. http://doi.org/10.1111/vop.12213.

Tanase, O., Pavli, C., Daraban, F., Velescu, E., 2014, "Consequences of hypovitaminosis A in captive turtlecase report", Lucrări Ştiințifice USAMV
Iaşi - seria Medicină Veterinară, 57(nr.3-4), pp. 293-296.

Zhang, Y., Song, T., Jin, Q., Huang, Y., Tang, X., Sun, X., Liu, F., Shang, Z., Bao, W., 2019, "Status of an alien turtle in city park waters and its potential threats to local biodiversity: the red-eared slider in Beijing", Urban Ecosystem, https://doi.org/10.1007/s11252-019$\underline{00897-z}$ 